\title{
English Borrowings from the Economic Sphere in the Verbal Lexicon of Native Speakers of Russian in the Era of Globalization
}

\author{
JULIA BALAKINA, ELENA VISILITSKAYA \\ Национальный исследовательский университет, Высшая школа экономики \\ в Нижнем Новгороде, ул. Большая Печерская, д. 25/12, RU-603155 Нижний Новгород \\ E-mail: julianaumova@gmail.com, visilena1@ rambler.ru
}

(Received: 6 December 2014; accepted: 21 March 2015)

\begin{abstract}
The article looks into the issue of the integration of loanwords appertaining to the financial lexis of the Russian language. Due to an overwhelming number of borrowings in the professional vocabulary of bank workers, the prevalence of anglicisms over Russian words in their written and verbal speech cannot go unnoticed. However, given a generally low level of bank workers' English language competence, this situation leads to peculiar, nonstandard adaptation of anglicisms at all language levels. Accordingly, the article presents the possible ways anglicisms integrate into the Russian language, and examines the native speakers' attitude to borrowed words and their preferences in using anglicisms. Furthermore, the authors have identified the main reasons why the speakers frequently resort to anglicisms and the degree of semantic awareness behind their choice. The most commonly-used borrowed terms have also been singled out.
\end{abstract}

Keywords: anglicisms, grammatical adaptation, graphic adaptation, financial vocabulary, banking sector

\section{Introduction}

In the era of globalization and exposure to international travel and foreign mass media, the number of loanwords coming into the system of the Russian language is drastically increasing. The most numerous borrowed terms can be found in the fields of micro- and macroeconomics, management, financial operations, funds, investment, marketing, and international trade. This tendency can be explained by the fact that after the fall of the Soviet Union, the planned social economy was at some point substituted by the market economy, which led to serious changes in people's mentality as well as in their lifestyle. A great number of different items, gadgets, and goods entered the life of a Russian citizen. As a result, there was a gap in the vocabulary to describe the technicalities of market capitalism. That could not but influence the language in the form of a great number of borrowings which were to be adopted along with the concepts they denote.

So, nowadays the Russian language is severely "barbarized" by loanwords mostly of English origin. A great many technical and professional jargon words have been imported to the Russian language and a number of new words have been coined. 
The explosion of the usage of Runglish ${ }^{1}$ is simply an attempt of the language to process the waterfall of concepts and terms which came down on it after the fall of the Iron Curtain.

The most active users of Runglish (along with teenagers and young people) are Russian professionals who regularly communicate in the English language. They are extensively exposed to it on a daily basis (webinars, conference calls, and e-mails from overseas colleagues) and are forced to appropriate and assimilate the borrowed terms, expressions, and concepts into Russian through adoption and adaptation. As a result, these - in a sense - exotic words now easily roll off the tongues of Russian-speaking people. The amazing thing about the transformation and evolution of the Russian language is the extent to how receptive the country's inhabitants are to English.

\section{Materials and methods}

The present article considers the complex process of adopting loanwords into the system of the Russian language at grammatical and graphic levels. The research involves lexical units belonging to the economic sphere, the richest in borrowings. Also, based on the results of a survey conducted among multinational bank employees aged 22-45, a number of conclusions have been drawn, which concern the degree of the integration of loans and the speakers' attitude towards them. The bank employees obviously confront a great number of borrowed terms in their everyday oral and written discourse at work that makes each of them practically contribute to the process of adaptation of loanwords in a unique way. It is evident that most of the bank employees do not have a good command of the English language. Hence, having to deal with a great number of unfamiliar terms from day to day, they try to make the application of these terms in their speech as easy as possible. Some of these ways have been revealed in our study and will be presented below.

Apart from the survey, the research has also been based on the corpus of borrowings which was compiled through reviewing linguistic and specialized papers and by analyzing different types of financial documents (e.g. reports, minutes of meetings, presentations, e-mails, memos, etc.).

\section{Reasons for borrowing}

Before turning to the ways of integration of loans into the system of the Russian language, we shall mention the basic reasons for borrowing.

Through linguistic osmosis (FREDEEN 2010), many thousands of words have been taken over from one language by another in the course of history. This process is inevitable and the reasons for it are miscellaneous. For example, it might

\footnotetext{
${ }^{1}$ Runglish (Ringlish, Ruglish, or Russlish - cf. the Russian terms рунглийский язык ог рунглиш) is a newly coined term meaning a Russian-English macaronic language; it is a jumbled jargon, a mixture of languages.
}

Studia Slavica Hung. 60, 2015 
be constant uninvited raids of invaders to the land (as in the history of English when the Roman invaders' language transformed Old English and a great many new words were adopted).

Traditionally, two main groups of reasons are distinguished: linguistic and extralinguistic ones (cf. VOLODARSKAYA 2001, FinK 1997, KUPPER 2003, DiAKOV 2003).

\subsection{Linguistic reasons}

It is undeniable that lexical units are borrowed into the recipient language to fill in lexical gaps, the so-called lacunas, when there is no corresponding lexical item to denote the borrowed concept. Thus, with the development of the banking system in Russia, such concepts as ATM, credit card, broker, discount, transaction, etc. have integrated into our life as well as into the language.

The results of the survey reveal that $10 \%$ of the respondents believe that the main reason for the usage of professional slang of foreign origin is that there are no language means in the Russian language for the concepts. $22 \%$ are sure that the lack of a more precise word in the recipient language or its evident disadvantage in the competition with a borrowed word is the main reason. $11 \%$ think that the main reason why they use professional slang of foreign origin is the opportunity to formulate the concept in a more accurate and precise way.

The economy of language means is also one of the reasons why borrowings are frequently used in the Russian language: $55 \%$ of the employees think that professional slang of foreign origin offers the opportunity to express oneself in a more concise way, with one word instead of a word combination or a phrase in Russian; there is a possibility "to squeeze" the information to achieve brevity, clarity, and convenience that actually means to save the speech effort and language means. At the same time, $38 \%$ only use highly specialized financial and banking terms of English origin which do not have a precise Russian equivalent.

There are two other linguistic reasons for borrowing to be mentioned, and namely: the need for synonyms (23\% use professional slang of foreign origin to vary and diversify the language means, to avoid repetition [synonymic sets]), and $11 \%$ of the surveyed believe that the main reason is the need to differentiate the concepts (i.e. пролонгировать 'to prolong' is mainly used in business context, while its Russian synonym продлять can be used in a more general context).

\subsection{Extralinguistic reasons}

The economic globalization, the special prestigious status of loanwords, and the growing interest in the English language constitute the extralinguistic reasons for borrowing.

According to the majority of the respondents (72\%), the globalization of all aspects of life, especially economic and social, is the main reason for the overflow of the Russian language with loanwords. 
$44 \%$ of those surveyed consider that the willingness to flaunt the foreign language to appear trendy is the main reason for English borrowings; $22 \%$ of the respondents are sure that science and technology development in the West has outpaced the development in Russia, bringing many foreign words into the Russian language; $11 \%$ of the employees believe that the imitation of and servility to the western lifestyle is the basic reason for borrowings; $5 \%$ of the participants are sure that dilettantism, illiteracy, the poor command of the native language and the lack of critical thinking are the main reasons.

The following facts are also relevant here: $57 \%$ of the respondents think that foreign words are trendy, fashionable, and prestigious; $42 \%$ believe that using loanwords helps to make the impression of a well-rounded person; $28 \%$ are sure that borrowings are clearer and more understandable; $14 \%$ tend to think that loans are more prestigious and sound more scientific; $14 \%$ consider borrowings to be more expressive, emphatic, and emotive; $14 \%$ believe that with the help of loans they can surprise and impress the partner.

The questionnaire results suggest that the borrowed terms used in professional and private life are not regarded by the speakers as unwanted and hostile. On the contrary, with the frequent use of loanwords, the native speakers make an attempt to fill in lexical gaps and, on the other hand, to emphasize the high level of their education and qualification.

It should be accentuated, however, that most loanwords from the economic sphere are truly necessitated. Due to the globalization of the world economy, and of banking sphere in particular, loanwords have become a must for the Russian language as they enable the speakers to fill in numerous lexical gaps, when no suitable equivalents can be found in the recipient language, and to satisfy the need to differentiate the concepts as in case of numerous synonyms.

\section{The ways of adaptation}

The number of loans in the Russian language is growing along with the development of the world economy. Most of these loanwords undergo all the stages of adoption: from a neologism to complete assimilation at all levels of the language. It is worth stressing here that graphic and morphological integration constitutes the most important stages, as it is impossible for any borrowing to become a full member of the system skipping them. Furthermore, graphic and morphological in tegration are also essential, as it is well-known that the economic vocabulary of native speakers of Russian is oversaturated with loanwords (mainly anglicisms). ${ }^{2}$ Sometimes people who have to use them every day at work do not have sufficient knowledge of the source language (predominantly English). So, they come across a number of difficulties concerning the comprehension and reproduction of nonassimilated lexical units, trying to adjust them to their own needs by making them similar to the native units in any possible way.

\footnotetext{
${ }^{2}$ An anglicism is a phenomenon found in Russian at the lexical or syntactic level whose form and/or meaning can be traced back to its English origin (BALAKINA 2011: 88).

Studia Slavica Hung. 60, 2015
} 
Presented below are the ways of integration of lacunar units of financial vocabulary at graphic and grammatical levels. These two levels have been chosen for the analysis as the most significant and revealing from the point of view of the adoption of financial terms.

\subsection{Graphic integration}

The adaptation of anglicisms into the graphic system of the Russian language is further complicated by the fact that the adopted units are originally rendered in the Latin alphabet, whereas Russian uses Cyrillic. Clearly, most anglicisms (ideally all of them) ought to be transferred from Latin to Cyrillic in order to become full members of the recipient language system.

This transfer can proceed in different ways. G. Timofeeva suggests three possibilities of adapting anglicisms to the graphic system of the Russian language: transplantation, transliteration, and transcription (cf. TIMOFEEVA 1995). But since these ways of integration do not cover all the examples of the anglicisms found in the corpus, hybrid spelling, and the mixed type (including both transliteration and transcription) need to be added.

\subsubsection{Transplantation}

Transplantation means that anglicisms are transferred into Russian in their original form preserving their Latin spelling. Moreover, they are not integrated into the grammatical system of the Russian language. For example:

Разработан Loan Application CheckList, дополняющий вышеуказанные рекомендации.

Cashflow model обязательна для всех сделок, подлежащих рассмотрению на GTCC.

Определение атрибутов для продукта payroll.

According to the results of the survey, transplantation is preferred in two cases. First of all, it can be called the first stage of the adoption of a foreign unit into the graphic system of the Russian language, as $68 \%$ of the respondents said that they used transplantation if the word was quite new. On the other hand, $20 \%$ use the Latin alphabet only if they know the correct English spelling, otherwise they prefer the Cyrillic one. That means that transplantation is more frequently used by people with a good command of the English language.

\subsubsection{Hybrid spelling}

The most typical case of hybrid spelling is when an anglicism preserves its original spelling, namely its stem; however, in order to function properly in the grammatical system, it acquires Cyrillic inflexions, which are spelt through an apostrophe or a hyphen. Also, there are some examples of hybrid compounds where one stem is rendered in Cyrillic, while the other preserves its original spelling: 
$P R$-деятельность вырабатывает лояльное отношение к марке, а BTL-акциии позволяют повышать объем продаж за счет прямого воздействия на конкретного покупателя «При использовании CRM-cucmeмbl в отделе продаж или в отделе обслуживания клиентов обеспечивается сохранение всей истории совершенных звонков и сообщений электронной почты.

Получить срез представлений руководителей об особенностях работы компаний $F M C G$-сектора с сетевой розницей.

The results of the survey show that the majority of respondents (82\%) use hybrid spelling only in compounds like push-проекm 'push project', check-листы 'check lists', CRM-система 'CRM system', cash flow-модель 'cash flow model', etc. $15 \%$ of the respondents spell hybrids in one word without a hyphen (pressoвamb, саshировать), and just 3\% prefer to use hyphenated hybrid words (press-овать, cash-ировать).

\subsubsection{Transliteration}

Transliteration can also be termed 'letter-by-letter' transfer. This method of representing anglicisms in Russian is based on the graphic principle, the phonological peculiarities of the transferred word being ignored. Here each letter of the source word is reproduced with the corresponding letter in Cyrillic. There is even a standard for Cyrillic-Latin transliteration (ГОСТ 7.79:2000 «Система стандартов по информации, библиотечному и издательскому делу. Правила транслитерации кирилловского письма латинским алфавитом»).

However, in some cases, one Russian grapheme requires more than one Latin grapheme. The next table lists correlations between the Russian and the English graphemes (monographs).

Table 1. The correspondence between Russian and English monographs

\begin{tabular}{|c|c|}
\hline English monograph & Russian grapheme \\
\hline A & А \\
\hline E & Е \\
\hline I & И \\
\hline O & О \\
\hline U & У \\
\hline В & Б \\
\hline C & К/C \\
\hline D & Д \\
\hline F & $Ф$ \\
\hline G & Г \\
\hline
\end{tabular}




\begin{tabular}{|c|c|}
\hline K & K \\
\hline$L$ & Л \\
\hline$M$ & $M$ \\
\hline$N$ & $H$ \\
\hline$P$ & $\Pi$ \\
\hline$R$ & $P$ \\
\hline$S$ & $C$ \\
\hline$T$ & $T$ \\
\hline$V$ & $B$ \\
\hline$Z$ & 3 \\
\hline
\end{tabular}

Transliteration is based on the principle of equivalence. Accordingly, it fails if there is no equivalence between an English monograph and a Russian grapheme.

The following English monographs do not have Russian equivalents, that is why they are not involved in the process of transliteration: $y, h, q, w, x, j$. They are transferred into the Russian language according to the rules of transcription: for example, target $\rightarrow$ maргет, commitment $\rightarrow$ коммитмент, performance $\rightarrow$ nерформанс, input $\rightarrow$ uнпут, detector $\rightarrow$ детектор, barter $\rightarrow$ бартер, broker $\rightarrow$ брокер, tender $\rightarrow$ тендер, marketing $\rightarrow$ маркетинг, monitoring $\rightarrow$ мониторинг, warrant $\rightarrow$ варрант, dealer $\rightarrow$ дилер, dividend $\rightarrow$ дивиденд, terminal $\rightarrow$ терминал, transit $\rightarrow$ транзит, benefit $\rightarrow$ бенефит, holding $\rightarrow$ холдинг, etc.

The results of the survey have also revealed that the majority (65\%) of those surveyed prefer to adapt anglicisms using transliteration.

\subsubsection{Transcription}

The sound image of an anglicism is reproduced with the letters that can express it in writing more precisely. That is to say, the pronunciation of the word is conveyed in writing.

The process of transcription is complicated by the fact that the phonetic systems of Russian and English differ drastically. Such English phonemes and diph-

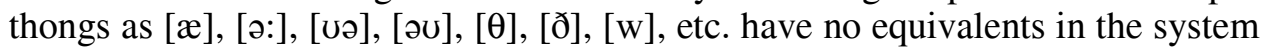
of Russian phonemes, which could be conveyed in writing.

Basically, the process of transcription comprises the following stages:

1. The graphic image of the word is transcribed: upgrade $\rightarrow$ [ $\Lambda$ pgreId];

2. An attempt is made to imitate the sound image of the English word by means of Russian phonemes: [ıpgreId] $\rightarrow$ [апгрэјд];

3 . The sound image, changed or at least adapted to the system of Russian phonemes, is again realized in writing, albeit with the help of Russian alphabet: [апгрэјд] $\rightarrow$ апгрейд. 
The whole process is hence as follows: upgrade $\rightarrow$ [^pgreId] $\rightarrow$ [апгрэјд] $\rightarrow$ апгрейд. For example, key objective $\rightarrow$ киобжектив/киообджектив, scope $\rightarrow$ скоуn, priority $\rightarrow$ прайорити, action plan $\rightarrow$ экшнплан, issue $\rightarrow$ ишью, scale $\rightarrow$ скейл, initiative $\rightarrow$ инишиатив, synergy $\rightarrow$ синерджи, complexity $\rightarrow$ комплексити, fine $\rightarrow$ файн, cash flow $\rightarrow$ кэшфлоу/кэшфоло, primary focus $\rightarrow$ праймари фокус, exесиtion $\rightarrow$ экзекюшн, сарасіty $\rightarrow$ капэсити, оррогtunity $\rightarrow$ оппортюнити /оппортунити, usability $\rightarrow$ юзабилити, update $\rightarrow$ andeйт, etc.

The means of transcription also appears complicated to the respondents. Only $35 \%$ of them choose transcription in writing. It happens due to the absence of diphthongs (gliding vowels [aг] $\rightarrow$ [ай], [ov] $\rightarrow$ [oy], etc.) and some other combination of sounds in the phonological system of the Russian language, as it has already been mentioned above.

\subsubsection{The mixed type}

Most of the anglicisms introduced into the graphic system of the Russian language are transferred with the help of both transliteration and transcription.

Typical examples include words with the suffixes -ing and -er. These suffixes are always transliterated as $-и н г$ and $-e p$, while the stem of the word can be transferred according to the rules of transcription: cf. branding $\rightarrow$ брэндинг, speaker $\rightarrow$ спикер, catering $\rightarrow$ кейтеринг, retailer $\rightarrow$ pитейлер, franchising $\rightarrow$ франчайзинг, leasing $\rightarrow$ лизинг, monitoring $\rightarrow$ мониторинг, merchandiser $\rightarrow$ мерчандайзер, хайринг $\rightarrow$ hiring, clearing $\rightarrow$ клиринг, overnight $\rightarrow$ овернайт, etc.

Sometimes, various ways of transition are applied to one and the same word. In this case, its varieties appear that exist side by side. Cf., for example, laptop $\rightarrow$ лаптоп/лэптоп/лептоп. The first variant is a case of transliteration, while the second and the third ones are the instances of transcription.

It is also relevant to note that $70 \%$ of the surveyed employees spell the borrowed neologisms they are familiar with using the Cyrillic script, while 30\% use both types of script indiscriminately. Also, $12 \%$ of the respondents encountering a new word in oral speech will spell it in Cyrillic; however, if they first meet the new foreign word in writing, they prefer to copy its image with the help of the Latin alphabet.

\section{Grammatical integration}

\subsection{Gender assignment of nouns (formal criteria)}

There are two main groups of criteria that influence gender assignment in Russian, namely, formal (morphological) criteria and semantic criteria (ARNDT 1970).

\subsubsection{Suffix analogy}

If there is an analogy between the suffix /inflexion of a borrowing and a native suffix, the borrowing is assigned to the gender commonly associated with this suffix / inflexion in the native language. 
In some cases, the suffix/inflexion can either preserve its original form or be replaced by the suffix/inflexion, which is typical of the target language. It should be pointed out that in Russian, the majority of adopted suffixes and inflexions are commonly transformed owing to the drastic differences in the phonological and graphic systems of English and Russian. Due to this reason, only the suffixes of Greek and Latin origin preserve their original form in Russian: e.g. -tion $\rightarrow-$-ия; -theraphy $\rightarrow$-терапия; -graphy $\rightarrow$-графия; -logy $\rightarrow$-логия; -mеtry $\rightarrow$-метрия; -сracy $\rightarrow$-кратия; -іс $(s) \rightarrow-$-иа.

In the economic sphere, the suffix analogy -tion $\rightarrow$-ция prevails: for example, diversification $\rightarrow$ диверсификачия, prolongation $\rightarrow$ пролонгация, fluctuation $\rightarrow$ флуктуачия, consignation $\rightarrow$ консигначия.

\subsubsection{Syllabicity}

A number of scholars (ZüRN 2001, CARSTENSEN 1965, GeSTER 2001) have proved that the number of syllables is directly related to the gender the noun is assigned to. It has been stated that most monosyllabic English borrowings in Russian are masculine. However, in this case gender assignment is motivated not only by the number of syllables but also by the form of the word, i.e. most borrowed monosyllabic nouns in Russian end in a hard consonant, that is why they are automatically assigned to the masculine gender: e.g. scope $\rightarrow$ cкоуn, case $\rightarrow$ кейc, fraud $\rightarrow$ фрод, trend $\rightarrow$ тренд, cost $\rightarrow$ кост.

\subsubsection{The form of the word}

In Russian, the most numerous and important criteria of the gender assignment of borrowings are related to the form of the word. The following principles are used to divide loans into the masculine, feminine, and neuter gender: ${ }^{3}$

a) Loanwords with a final hard consonant are masculine: target $\rightarrow$ mapzem, feedback $\rightarrow$ фидбэк, pipeline $\rightarrow$ пайплайн, overhead $\rightarrow$ оверхэд, detention $\rightarrow$ детеншен, audit $\rightarrow$ aydum, leasing $\rightarrow$ лизинг, inриt $\rightarrow$ инпут.

The results of the survey also support this statement as $100 \%$ of the respondents regard nouns ending in a hard consonant as part of the masculine gender.

b) Loanwords ending in $-a(-я)$ are feminine: ${ }^{4}$ franchise $\rightarrow$ франшиза, synergy $\rightarrow$ синергия, margin $\rightarrow$ маржа, recession $\rightarrow$ рецессия.

c) Loanwords ending in $-u,-y,-ю,-e,-o$ are neuter: cash flow $\rightarrow \kappa э щ-ф л о$, know how $\rightarrow$ ноу-хаy, opportunity $\rightarrow$ oпnортунити, case study $\rightarrow$ кейс-стади, royalty $\rightarrow$ роялти, usability $\rightarrow$ юзабилити.

However, the loanwords ending in $-u$ such as opportunity $\rightarrow$ onnopтунити or usability $\rightarrow$ юзабилити are often traced to the feminine gender, due to the next semantic equivalent: оппортунити 'возможность' (feminine gender) and юзабилити 'используемость' (feminine gender). The loan royalty $\rightarrow$ роялти can be

\footnotetext{
${ }^{3}$ The following rules concern only declinable nouns denoting inanimate objects.

${ }^{4}$ Here the native suffixes are attached to the original stems.
} 
considered a pluralia tantum noun because of the suffix $-u$, which is a typical plural ending in Russian: Он получил хорошие роялти 'He received good royalty'.

d) Most nouns that end in $-e$ are masculine in Russian because when the mute ending - $e$ disappears, the noun comes to end in a hard consonant serving as a mark of the masculine gender (offshore $\rightarrow$ opwop, update $\rightarrow$ andeüm, performance $\rightarrow$ перформанс). $98 \%$ of the surveyed consider nouns that end in $-e$ to be masculine in Russian too, and just only $2 \%$ of them have traced the anglicism pipeline to the feminine gender, by the analogy with Russian линия 'a line' (feminine gender).

e) Nouns ending in $-l$ in English become $-l$ ' in Russian and behave like native nouns ending in $-l$, which means that they can either be assigned to the masculine or feminine gender: e.g. on call $\rightarrow$ онколь (masculine gender), model $\rightarrow$ модель (feminine gender). However, this rule is frequently ignored in modern Russian: for instance, scale $\rightarrow$ скейл and goodwill $\rightarrow$ гудвил both end in $-l$ and are assigned to the masculine gender.

A separate group of nouns constitute the loans that preserve their original graphic form. In this case gender assignment depends on the sound image of the word in general and on the suffix/inflexion in particular. For example, a compound noun WatchList is assigned to the masculine gender, as the determiner is a monosyllabic noun ending in a hard consonant.

WatchList у меня сейчас полностью заполнен.

\subsection{Gender assignment of nouns (semantic criteria)}

\subsubsection{Natural gender}

Russian nouns denoting persons are ascribed to a certain gender on the basis of the sex of the person they denote.

Sometimes the criterion of natural gender can be supported by some other means, namely particular suffixes help to define it: риэлториа (a woman realtor), ayдиториа (a woman auditor) (colloquial).

Another way of defining the gender of nouns denoting persons exists in Russian - compounds with one of the components denoting the person's sex can be created: тетка-менеджер (a woman manager - vulgar).

There is also a syntactic way of distinguishing the gender of nouns denoting persons. The use of pronouns or adjectives in context helps to determine it:

Есть точки, на которых мы определяем, что бизнес должен сделать к этому времени, что наш кофаундер или наш лидер компании должен достичь к этому моменту.

In some cases, the choice of gender is influenced by the next lexical synonym in the recipient languages or by the nearest semantic equivalent. This happens mostly in cases when borrowings are not marked for a particular gender by a suffix/inflexion or there is no graphic or phonological similarity with the native equivalent. The use of this criterion in gender assignment is questionable. 
Here are some examples from above, in which gender assignment depends on the nearest semantic equivalent. The loans ending in $-u$ such as onnортунити or юзабилити are often traced to the feminine gender: оппортунити 'возможность' (feminine gender) and юзабилити 'используемость' (feminine gender).

\subsection{Plural formation}

In Russian, there is no plural ending $-s$, and although it can be preserved in loanwords, it is not perceived like a plural ending. The following ways of forming the plural form of English borrowings with the ending $-s$ are possible:

1 . The plural ending $-s$ is preserved but treated like a part of the stem, with the Russian plural ending $-b l$ added to form the plural: Windows $\rightarrow$ виндоусы, fees $\rightarrow$ pucbl.

2. The plural ending $-s$ is substituted by Russian endings: costs $\rightarrow$ kocmbl, workshops $\rightarrow$ воркшопы, trainings $\rightarrow$ тренинги.

\subsection{Borrowed verbs}

Borrowed verbs in Russian are integrated into the system of conjugation. They take the suffixes $-u-/-a-/-о в a-$ and are accordingly ascribed to one of the two conjugations: the 1st (пролонгировать, кэшировать) or the 2nd one (вафлить).

\subsection{Borrowed adjectives}

Whether adjectives are inflected or not, mainly depends on their function in a sentence and on the degree of integration.

Already integrated adjectives in the attributive position are inflected just like native ones in Russian: e.g. консолидированный, маржинальный.

Adjectives that fulfill a predicative function or that are used attributively as constituents of a lexical unit are not inflected: ${ }^{5}$ e.g. фри-аут, клиент сегмента ворк-аут, праймари фокус, еtс.

\section{Conclusion}

To draw a line, it shall be mentioned that although some linguists argue over the negative and positive influence of loanwords on a recipient language, the material analyzed and the survey conducted plainly reveal that technical and professional jargon words which have been imported to the Russian language do not compete with native words. On the contrary, they diversify the vocabulary and hardly affect the "structure" of speech. They are "simply the adoption of names for particular things" (Greenough-KitTredGe 1962).

As to the integration of foreign units, the following conclusion can be drawn: despite the fact that borrowed terms go through a certain adaptation process at both the graphic and grammatical levels, in most cases, they fully or partly retain

\footnotetext{
${ }^{5}$ Adjectives as constituents of a lexical unit are looked upon as a part of a compound.
} 
their foreign image, i.e. their origin is recognized at first glance. The study has also demonstrated that if native speakers confront an anglicism in a written discourse, then they tend to copy its original form, i.e. Latin spelling, and reproduce it accordingly in the written texts of their own. Yet, facing a foreign neologism for the first time in oral speech, the majority of native speakers will use the Cyrillic script to reproduce it in writing, using both transliteration and transcription. This tendency reveals that native speakers of Russian still have insufficient knowledge of the English language.

Generally speaking, an extensive usage of compression, condensation, and reduction mechanisms is due to extralinguistic factors (the need to differentiate and clarify the concepts) as well as to the internal laws of language (the economy of speech effort and language means).

Finally, it is worth noting that native Russian speakers' positive attitude to loanwords brings about an ongoing increase in their number. We can also assume that due to a growing number of borrowings, a tendency to simplify their adaptation at all levels of the Russian language is likely to be observed in the future, which could in the long run lead to global changes in the Russian language system, like the prevalence of analytical structures over synthetic ones.

\section{References}

ARNDT $1970=$ ARNDT W. Non-random assignment of loanwords. German noun gender. Word 26 (1970): 244-253.

BalaKInA 2011 = BALAKINA J. Anglicisms in Russian and German Blogs. Frankfurt am Main: Peter Lang, 2011.

CARSTENSEN 1965 = CARSTENSEN B. Englische Einflüsse auf die Deutsche Sprache nach 1945. Heidelberg: Carl Winter Universitätsverlag, 1965.

DIAKOV 2003 = Дьяков А. И. Причины интенсивного заимствования англицизмов в современном русском языке. В кн.: Язык и культура. Новосибирск, 2003. 35-43.

FINK 1997 = FINK H. Von Kuh-Look bis Fit for Fun. Anglizismen in der heutigen deutschen Allgemein- und Werbesprache. Frankfurt am Main: Peter Lang, 1997.

FREDEEN 2010 = FREDEEN Ch. Borrowed Words in English. http://www.danshort.com/ie/ borrowedwords.htm.

GESTER 2001 = GESTER S. Anglizismen im Tschechischen und im Deutschen. Bestandaufnahme und empirische Analyse im Jahr 2000. Frankfurt am Main: Peter Lang, 2001.

Greenough-Kittredge 1962 = Greenough J. B., Kittredge G. L. Words and Their Ways in English Speech. Boston: Beacon Press, 1962.

KUPPER 2003 = KUPPER S. Anglizismen in deutschen und französischen Werbeanzeigen . Zum Umgang von Deutschen und Französen mit Anglizismen. Marburg: Tectum Verlag, 2003.

TIMOFEEVA 1995 = ТИМОФЕЕВА Г. Г. Новые английские заимствования в русском языке. Написание. Произношение. Санкт-Петербург: «Юна», 1995.

VOLODARSKAYA 2001 = ВоЛОДАРСКАЯ Э. Ф. Заимствование как универсальное лингвистическое явление. Вопросы филологии 2001/1: 11-28.

ZÜRN 2001 = ZÜRN A. Anglizismen in Deutschen: am Beispiel des Nachrichtenmagazins Der Spiegel. Tübingen: Niemeyer, 2001. 


\section{Appendix A: The Questionnaire}

Please answer the following questions. Choose the response that seems to you the most appropriate at first glance. We appreciate your opinion.

1. What is your age?

A) 18-25, B) 26-35, C) 36-40, D) 41-45, E) 46-50, F) 51 and over

2. Look at the following list of words:

\begin{tabular}{|l|l|}
\hline таргет (target) & иель \\
\hline фидбэк (feedback) & ответ \\
\hline дедлайн (deadline) & конечный срок \\
\hline кооперация (cooperation) & сотрудничество \\
\hline дефолт (default) & неплатежеспособность \\
\hline транзакция (transaction) & сделка \\
\hline ресёрч (research) & исследование \\
\hline рекрутинг (recruiting) & найм \\
\hline пролонгировать (to prolong) & продлять \\
\hline
\end{tabular}

Words from which column do you like more? Why? (They sound nicer, and look more familiar, understandable, fashionable, or pleasant to you, they are easier to pronounce, or other...)

3. What is your attitude to the abundance of anglicisms in the Russian language?

A) I am positive about it. English is the language of international communication.

B) I tolerate it. It is inevitable in the era of globalization.

C) I am negative about it. I am in favour of the pure Russian language.

D) I do not care. I have not thought about it.

4. What do you think is the main reason for the overflow of the Russian language with loanwords? You can choose from several options:

A) Dilettantism, illiteracy, and poor command of the native language.

B) Imitation and servility to the western lifestyle.

C) Willingness to flaunt the English language (fashion).

D) The globalization of all aspects of life, especially economic and social.

E) Frequent travelling and extensive communication with foreigners.

F) Intensive language learning.

G) Science and technology development in the West has outpaced the development in Russia, bringing in many foreign words into the Russian language.

H) Other... 
5. How often do you use anglicisms in your speech at work?

A) Often. It is easier for my colleagues. They understand me better.

B) Often. It is easier for me - they are shorter and clearer.

C) Not often. I try to replace borrowed words with Russian equivalents so that co-workers and clients better understand me.

D) Not often, because sometimes I do not clearly understand the meaning of a borrowed word.

E) Rarely. I only use highly specialized financial and banking terms of English origin that do not have a precise Russian equivalent.

F) Only in documents and business correspondence. In oral speech, I try to limit myself to the use of native language.

G) I do not use them at all.

6. If you use professional slang of foreign origin, please give the main reasons for it. You can choose from several options:

A) The opportunity to express oneself in a more concise way, with one word instead of a word combination or a phrase in Russian; when there is a possibility to compress the information for the sake of brevity, clarity, and convenience (to save speech effort and language means).

B) The need to differentiate the concepts, e.g. пролонгировать is mainly used in business context, while its synonym продлять can be used in a more general context.

C) The need to vary and diversify the language means, to avoid repetition (synonymic sets).

D) It expresses the concept in a more accurate and precise way.

E) The lack of a more precise word in the recipient language or its evident disadvantage in competition with the borrowed word.

F) There are no language means in the Russian language for the concept.

G) I do not use professional slang of foreign origin.

7. Do you always try to learn the Russian equivalent of a borrowed word?

A) Yes. I need it for complete understanding and for the correct word usage.

B) Sometimes.

C) No, I guess from the context what it is all about.

8. Do you use foreign words outside work in your everyday life? (e.g. драйв, киллер, лифтинг, мани, пилинг, ремейк, тренд, уик-энд, хот-дог, еtс.)

A) Yes, I regularly use them in everyday life.

B) Yes, but rarely. I only use professional slang when speaking about my job.

C) I only use them on social networking sites.

D) I only use them for language study (revision and consolidation of vocabulary).

E) No, I do not use them in everyday life. I only use them with co-workers and clients at work.

F) I do not accept using foreign words in the native language. I am in favour of native language purity. 
9. Why do you think Russians frequently use words of English origin? You can choose from several options:

A) They are more "prestigious" and sound more scientific.

B) They are more expressive, emphatic, and emotive.

C) They are more aesthetically pleasing.

D) They are clearer and more understandable.

E) They are trendy, fashionable, and prestigious.

F) They help to make the impression of a well-rounded person.

G) They help to surprise and to impress the partner.

H) They create an image of uniqueness, importance, and novelty.

10. What are the advantages of native Russian words over their synonyms of English origin? You can choose from several options:
A) Russian words sound better.
B) They are more familiar.
C) Everybody understands me.
D) They are easier to pronounce.
E) I do not see any advantages.

11. What words of English origin do you use more often?

12. Tick the words you are familiar with and underline those you have seen for the first time:

айпио, апоинтмент, капасити, кипиай, кост, кэш флоу, марджин, нетворкинг, обждектив, пайплайн, прайорити, ресешн (рецессия), синерджи, фидбэк, форфитинг, хеджер, эксплоужа, экспоужа

13. Write down the words you are familiar with in the same graphic form with the help of either the Cyrillic or Latin alphabet you might use in e-mails and other documents.

14. What gender do you think these words belong to? Specify the gender next to the words:

\begin{tabular}{|c|c|c|c|}
\hline Word & Gender & Word & Gender \\
\hline explosure (эксплоужа) & & priority (прайорити) & \\
\hline cost $($ кocm $)$ & & KPI (кипиай) & \\
\hline capacity (капасити) & & cash flow (кэш флоу) & \\
\hline IPO (айпио $)$ & & recession (ресешн) & \\
\hline objective (обждектив) & & forfeiting (форфитинг) & \\
\hline margin (марджин) & & appointment (апоинтмент) & \\
\hline hedger (хеджер) & & networking (нетворкинг) & \\
\hline pipeline (пайплайн) & & exposure (экспоужа) & \\
\hline feedback (фидбэк) & & sуnergy (синерджи) & \\
\hline
\end{tabular}


15. How do you prefer to spell foreign words?

A) I prefer to use Latin spelling (e.g. cost).

B) I usually use Cyrillic alphabet (e.g. $\mathrm{kocm}$ ).

C) I use Latin alphabet only if I know the correct English spelling; otherwise I prefer Cyrillic.

D) If I encounter a new word in oral speech, I will spell it in Cyrillic; if I first meet a new foreign word in writing, I prefer to copy its image using the Latin alphabet.

E) If I encounter the word on a daily basis, I prefer to use Cyrillic, if the word is quite new, I spell it in English.

16. Do you use hybrid spelling? (e.g. costbl, appointmentbl, term-листы, wafflumь)
A) Often.
B) Not often. I prefer to use either the Cyrillic or the Latin alphabet.
C) Never.

17. If you use hybrid words, how do you spell them?

A) I write hybrids in one word without a hyphen (e.g. саshировать, ргеssовать).

B) I prefer to use hyphenated hybrid words (e.g. cash-ировать, press-овать).

C) I use hybrid spelling only in compounds (e.g. pиsh-проект, check-листы, CRM-система, cash flow-модель).

18. Look at the list of words. Tick the words which you prefer or use more often:

\begin{tabular}{|l|l|}
\hline нетворкинг (networking) & нетвокинг \\
\hline синержи (synergy) & синерджи \\
\hline рисерч (research) & рисеч \\
\hline паплайн (pipeline) & пайплайн \\
\hline кэш фло (cash flow) & кэш флоу \\
\hline обжектив (objective) & обджектив \\
\hline маржин (margin) & маджин \\
\hline приорити (priority) & прайорити \\
\hline
\end{tabular}

Thank you! 


\section{Appendix B: The Results}

Multinational bank employees aged 22-45 took part in the survey. All the respondents are native Russian speakers. (In some questions, several options were allowed therefore the results can be more than $100 \%$ total.)

\section{Attitude}

$16 \%$ of the employees have a positive attitude to a large number of neologisms originated from the English language, saying that English is the language of international communication.

More than half of the respondents $(66 \%)$ are tolerant to loanwords because in the globalization era this linguistic process is predictable and inevitable.

$11 \%$ of the participants are strongly against the abundance of foreign words in Russian. They are in favour of the native language purity.

2. Reasons for the overflow of the Russian language with loanwords

According to the majority of those surveyed (72\%), the main reason for the overflow of the Russian language with loanwords is the globalization of all aspects of life, especially economic and social.

$44 \%$ consider fashion and the willingness to flaunt the foreign language to be the main reason for English borrowings.

$22 \%$ are sure that science and technology development in the West has outpaced the development in Russia, bringing many foreign words into the Russian language.

$11 \%$ believe imitation and servility to the western lifestyle to be the basic reason for borrowings.

$5 \%$ are sure that dilettantism, illiteracy, the poor command of the native language, and the lack of critical thinking are the main reasons.

\section{The frequency of usage of borrowings}

$38 \%$ of the respondents rarely use foreign words. They only use highly specialized financial and banking terms of the English origin which do not have a precise Russian equivalent.

$22 \%$ do not use loanwords very often. They try to replace borrowed words with their Russian equivalents so that co-workers and clients can understand them better.

$16 \%$ often use borrowings because they are shorter and clearer, and also because the colleagues understand them better.

$16 \%$ use loanwords only in documents and business correspondence. In oral speech, they try to limit themselves to the use of the native language.

4. Reasons for the usage of professional slang of foreign origin (the advantages of anglicisms over their Russian equivalents) - linguistic factors

$55 \%$ of the employees think that the main reason for the usage of professional slang of foreign origin is the opportunity to express oneself in a more concise way, with one word instead of a word combination or a phrase in Russian when there is a possibility to compress 
the information for the sake of brevity, clarity, and convenience (to save speech effort and language means).

$23 \%$ believe that the main reason for the usage of professional slang of foreign origin is the need to vary and diversify the language means and to avoid repetition (synonymic sets).

$22 \%$ are sure that the lack of a more precise word in the recipient language or its evident disadvantage in competition with the borrowed word is the main reason.

$11 \%$ believe that the main reason is the need to differentiate the concepts (e.g. пролонгировать is mainly used in business context, while its synonym продлять can be used in a more general context).

$11 \%$ think that the main reason for the usage of professional slang of foreign origin is the opportunity to express the concept in a more accurate and precise way.

$10 \%$ believe that the main reason for the usage of professional slang of foreign origin is that there are no native words in the Russian language to describe the concepts.

5. Reasons for the usage of professional slang of foreign origin (the advantages of anglicisms over their Russian equivalents) - extralinguistic factors

$57 \%$ of the employees think that it is trendy, fashionable, and prestigious.

$42 \%$ believe that it helps to make the impression of a well-rounded person.

$28 \%$ are sure it is clearer and more understandable.

$14 \%$ think that it is more "prestigious" and sounds more scientific.

$14 \%$ think that it is more expressive, emphatic, and emotive.

$14 \%$ believe that it helps to surprise, to impress the partner.

\section{Translation}

$78 \%$ of the participants need a Russian translation to understand a borrowing completely and to use it correctly.

$22 \%$ do not need the translation; they guess its meaning from the context.

7. The usage of borrowings outside work

$58 \%$ regularly use borrowings in everyday life.

$28 \%$ rarely use borrowings in everyday life.

$14 \%$ use them only for language study (revision and consolidation of vocabulary).

8. The advantages of Russian words over their synonyms of the English origin

$86 \%$ say that everybody understands them.

$28 \%$ mean that Russian words sound better.

$28 \%$ believe that they are easier to pronounce.

$14 \%$ claim that they are more familiar.

9. The spelling of familiar and unfamiliar foreign words

Native Russian speakers were offered a set of loanwords, both familiar (which they have come across) and unfamiliar. 
$70 \%$ of the surveyed spell the borrowed neologisms they are familiar with using the Cyrillic script.

$30 \%$ of the employees use both types of script indiscriminately.

$68 \%$ of the respondents spell loanwords they encounter on a daily basis with the help of Cyrillic (using transliteration or transcription), and if the word is quite new they prefer transplantation (Anglicisms are transferred into Russian in their original form preserving their Latin spelling).

$20 \%$ use the Latin alphabet only if they know the correct English spelling, otherwise they prefer Cyrillic.

$12 \%$ will spell a new word in Russian if they encounter it in oral speech; however, if they first meet the new foreign word in writing, they prefer to copy its image using the Latin alphabet.

\section{Gender assignment}

$100 \%$ of the respondents regard nouns ending in a hard consonant as belonging to the masculine gender.

98\% consider that nouns ending in mute $-e$ are also masculine in Russian because when the ending - $e$ disappears, the noun comes to end in a hard consonant, which is a mark of the masculine gender (e.g. обждектив, пайплайн).

$2 \%$ of the respondents consider the word pipeline to be of feminine gender in Russian, by the analogy with Russian линия 'a line' (feminine gender).

\section{Hybrids}

Most of the respondents (82\%) use hybrid spelling only in compounds (e.g. push-nроекm, check-листы, CRM-система, cash flow-модель).

$15 \%$ write hybrids in one word without a hyphen (саshировать, pressoвать).

$3 \%$ prefer to use hyphenated hybrid words (cash-ировать, press-овать).

\section{Graphic adaptation}

The majority (65\%) of the respondents prefer to adopt Anglicisms using transliteration (the graphic image of the word is more important than the phonetics).

Transcription is less preferred (35\%) due to the absence of diphthongs (gliding vowels [ar] $\rightarrow$ [ай], [ou] $\rightarrow$ [oy]) and some combination of sounds in the phonological system of the Russian language. 